\title{
WETLAND ALGAL COMMUNITIES FROM BALTA MICĂ A BRĂILEI NATURE PARK (ROMANIA)
}

\author{
Mihaela Hrisa FLORESCU *, Maria Magdalena MAXIM *, \\ Laura MOMEU *, Mirela CIMMPEAN * and Karina Paula BATTES * \\ * "Babeş-Bolyai” University, Faculty of Biology and Geology, Department of Taxonomy and Ecology, \\ Clinicilor Street 5-7, RO-400006, florescuhrisa@yahoo.com, madalina_910@yahoo.com, \\ lmomeu@yahoo.com, mirela_cimpean@yahoo.com
}

DOI: 10.1515/trser-2015-0061

KEYWORDS: floodplain lakes, phytoplankton, phytobenthos, similarity, species richness, water quality.

\section{ABSTRACT}

The present paper aims to characterize the algal communities from Balta Mică a Brăilei Nature Park in terms of their species richness and their ability to reflect the water quality of the aquatic ecosystems they live in. Thirteen shallow floodplain lakes, both permanent and temporary, were considered for the present study, with 16 sampling occasions in 2012 and 2013. More than 300 algal taxa were identified, with the green algae (Chlorophyta) being the dominant phyla in almost all the sampling sites. The trophicity and the organic pollution reached high values in 2012, probably due to low water levels caused by drought. Spring floods from 2013 led to lower trophicity and saprobity levels in all sampled water pools. (Roumanie).

RÉSUMÉ: Les communautés d’algues du Parc Naturel Balta Mică à Brăilei

Le présent article vise à caractériser les communautés d'algues du Parc Naturel Balta Mică à Brăilei, en fonction de leur richesse en espèces et de leur capacité à refléter la qualité des écosystèmes aquatiques. Treize lacs peu profonds, permanents ou temporaires, ont été considérés pour la présente étude, avec 16 occasions d'échantillonnage en 2012 et 2013 . Plus de 300 taxons d'algues ont été identifiés; les algues vertes (Chlorophyta) ont été dominantes dans presque tous les sites d'échantillonnage. La trophicité et la pollution organique ont enregistré des valeurs élevées en 2012, probablement en raison de faibles niveaux d'eau causés par la sécheresse. Les inondations du printemps 2013 ont conduit aux niveaux inférieurs de trophicité et de pollution organique dans les tous les lacs échantillonnés.

REZUMAT: Comunităţile algale din Parcul Natural Balta Mică a Brăilei (România).

Lucrarea de față are ca scop caracterizarea comunităţilor algale din Parcul Natural Balta Mică a Brăilei din punctul de vedere al bogăției specifice, luând în considerare și informațiile valoroase pe care aceste comunități le pot aduce în ceea ce privește calitatea apei în ecosistemele acvatice în care trăiesc. Treisprezece lacuri, atât permanente cât și temporare, au fost luate în considerare pentru prezentul studiu, cu 16 prelevări în 2012 și 2013. Peste 300 de taxoni algali au fost identificați, algele verzi (Chlorophyta) fiind grupul dominant la majoritatea stațiilor de prelevare. Troficitatea și saprobitatea lacurilor considerate, calculate pe baza a trei indici specifici comunităților algale, au avut niveluri ridicate în lunile de prelevare din 2012, datorită secetei prelungite care a dus la scăderi drastice ale nivelului apei în lacuri, dar mai reduse în aprilie și iunie 2013, datorită inundațiilor care au condus la creșteri semnificative a volumului de apă din zona inundabilă. 


\section{INTRODUCTION}

Algae inhabit most freshwater environments, playing a core role in aquatic food webs, being one of the three major groups of photosynthetic organisms, along with macrophytes and bacteria. Algae are also important in relation to human use of natural resources, because they respond quickly to any changes in the status of their environment, whether natural or humaninduced (Suthers and Rissik, 2009). Thus, algal bioindicators of water quality are particularly important in terms of eutrophication and saprobity (the amount of decomposing organic matter existing in the system) (Bellinger and Sigee, 2010). In fact, the current European legislation in the field of water policy, the Water Framework Directive (2000/60/EC), aims to maintain and improve the water quality of EU water bodies, and indicates phytoplankton, macrophytes and phytobenthos as quality elements for the classification of ecological status in lakes.

Wetlands comprise a range of aquatic habitats, from peat lands to shallow lakes, not exceeding six m in depth, according to the Ramsar Convention on Wetlands of International Importance (1971). Due to their shallow depth, wetlands are not usually stratified, with the photic zone extending to the sediments (Moore, 2008). Thus, wetland algal communities are both planktonic and benthic, because the free-floating and rooted macrophytes that usually dominate wetlands provide a rich substratum for epiphytic algae (Bellinger and Sigee, 2010).

Balta Mică a Brăilei Nature Park ("Small Island of Brăila" in the annotated Ramsar list of wetlands of international importance, www.ramsar.org) represents a group of wetlands located on the Lower Danube, South-East Romania, stretching between kilometers 176 and 238 of the river Danube, just upstream of Brăila, at an altitude ranging between three and nine $\mathrm{m}$ a.s.l. (Dimitriu et al., 2009). The area includes temporary or permanent floodplain lakes, marshes, connecting canals, islands, the Danube arms and the river itself, covering a total area of 17,586 ha. The natural hydrological conditions are maintained by human activity in Balta Mică a Brăilei area. In fact, the region represents a mixture of inter-connected terrestrial and aquatic ecosystems, with no strict boundaries between them, but strongly dependent on seasonal floods (Stănescu et al., 2009). The Nature Park is an important conservation area: in 2001, the area was declared a Wetland of International Importance (Ramsar site no. 1074) and since 2008 it has been included in Natura 2000 networks, both as a Site of Community Importance (SCI) and as a Special Area for Bird Protection (SPA) (Brînzan, 2013).

Despite the major ecological value of Balta Mică a Brăilei, few scientific works regarding algal communities have been published from the region. We focused on articles from the wetland itself, and not from the Danube River, since the present paper deals solely with the floodplain lakes within the Nature Park. However, the previous literature is either old (Antonescu et al., 1952, from Cărăuș, 2012), or dealing with macroscopic algae like Characeae (Ionescu - Țeculescu, 1966/1967, from Cărăuș 2012), or unpublished (Adamescu, personal communication). A total number of 176 planktonic algal species are mentioned on the official website of the Nature Park (www.bmb.ro).

That is why the present paper represents an important update on the algal flora from the Balta Mică a Brăilei area, aiming to: 1) characterize the algal communities from the region; 2) describe the algal species richness from 13 floodplain lakes; and 3) assess the water quality from the sampling sites based on ecological indices.

\section{MATERIALS AND METHODS}

The samples were collected in 2012 (June, July and September) and in 2013 (April and June), from 13 sampling sites on 16 occasions, with Lakes Lupoiu, Curcubeu and Bordeiele being sampled twice (Tab. 1). L1 is the sampling site; DD is the day, MM the month and YY the year of the samplings. Thus, L1_14.06.12 represents lake Japșa, sampled in 14th of June 2012, for the example L1_DD.MM.YY. 
The characteristics of the sampled lakes depend mainly on the regional climatic variations. Thus, extended drought periods were recorded in 2012, which clearly influenced the water volume from the floodplain lakes: for example, the mean July temperature in 2012 was $26-28^{\circ} \mathrm{C}$, with $4-6^{\circ} \mathrm{C}$ deviation against the multiannual mean from 1961 to 1990, with precipitation volumes not exceeding 10-20 $\mathrm{mm}$ in the Balta Mică a Brăilei area (data source: National Meteorological Administration, www.meteoromania.ro). These factors led to drastic drops of the water levels in all water bodies from the region. On the other hand, catastrophic floods took place in the upper and middle stretches of the Danube in spring 2013, with consequences on the water discharge of the river in the Balta Mică a Brăilei region (data source: National Institute of Hydrology and Water Management, www.inhga.ro). In fact, if we consider the mean Danube discharge values at Vadu Oii, Constanța County, just upstream of the Nature Park, we can divide the sampling periods into two categories: 1) months with low discharge values (June, July and September 2012, with discharges of 6,870, 4,340 and $3,040 \mathrm{~m}^{3} / \mathrm{sec}$., respectively); and 2) months with high discharge values (April and June 2013, with 12,220 and 8,900 $\mathrm{m}^{3} / \mathrm{sec}$., respectively) (data source: National Institute of Hydrology and Water Management, www.inhga.ro).

Seven sampling sites were located in the southern region of the Nature Park: lakes Japșa, Sbenghiosu, Lupoiu, Jigara, Curcubeu, Gâsca and Cortele (L1-L7); one site was located in the central area: lake Cucova (L8); while five sites were situated in the northern area: Lakes Lupu, Bordeiele, Stan, Iezerul Morilor and Chiriloaia (L9-L13) (Tab. 1; Fig. 1).

Most of the water bodies included for sampling were permanent shallow lakes, rich in submerged, emerged and floating vegetation; often connected with each other and with the Danube River or its arms. In a study conducted in the summer of 2008, Stănescu et al. (2009) characterized these permanent water pools as shallow, with a maximum water depth of $150 \mathrm{~cm}$ and an average depth of $85 \mathrm{~cm}$; with smooth, indefinite shorelines created from alluvia transported inwards and outwards during floods. The largest lakes in terms of their surface were the following: lake Curcubeu (296 ha), lake Lupoiu (272 ha), lake Jigara (244 ha), lake Gâsca (203 ha) and lake Cucova (236 ha) (Stănescu et al., 2009).

Lake Japșa (L1) was the only temporary water pool from the 13 sites included in the present study. These temporary water bodies from the Balta Mică a Brăilei area usually become marshes in drought periods, having a shallower depth compared to permanent pools, not exceeding $100 \mathrm{~cm}$, with a mean depth of $55 \mathrm{~cm}$ (Stănescu et al., 2009).

The altitude differences between the floodplain lakes included in this study were minimal. In fact, the mean slope of the water surface was about $0.02 \%$ in the $83 \mathrm{~km}$ long Danube sector between Hârşova and Brăila (which includes our study area), meaning a drop of two $\mathrm{cm}$ in the water level for each river kilometer, when going downstream (Dimitriu et al., 2009). More importantly, the reference value of the Danube low water level was deeper compared to its floodplain lakes, so the general tendency of the waters in this area was to flow towards the stream beds of the Danube and its arms (Stănescu et al., 2009).

The samples were collected using a $30 \mu \mathrm{m}$ mesh size phytoplankton net, and preserved in $4 \%$ formaldehyde. Several physical and chemical parameters were also measured at each site, using portable meters (Consort P902 for pH and YSI 52 for dissolved oxygen and water temperature). Identifications were made to the species level (Ettl and Gärtner, 1988; Komárek and Anagnostidis, 2005; Krammer and Lange, 1986; Popovsky and Pfiester, 1990; Wolowski, 2005). 
Table 1: The sampling sites located in the Balta Mică a Brăilei Nature Park.

\begin{tabular}{|c|c|c|c|c|}
\hline $\begin{array}{l}\text { Sampling site } \\
\text { code }\end{array}$ & $\begin{array}{l}\text { Lake } \\
\text { name }\end{array}$ & $\begin{array}{c}\text { Sampling } \\
\text { date }\end{array}$ & $\begin{array}{c}\text { GPS } \\
\text { coordinates }\end{array}$ & $\begin{array}{l}\text { Maximum depth } \\
\text { (m) }\end{array}$ \\
\hline L1_14.06.12 & Lake Japşa & 14.06.2012 & $\begin{array}{l}\text { N 4448’06.5”' } \\
\text { E 2750'17.5” }\end{array}$ & 0.60 \\
\hline L2_19.07.12 & Lake Sbenghiosu & 19.07.2012 & 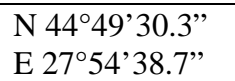 & 1.50 \\
\hline L3_18.07.12 & \multirow[t]{2}{*}{ Lake Lupoiu } & 18.07.2012 & N 445ㅇ'43.8”' & 0.70 \\
\hline L3_22.06.13 & & 22.06 .2013 & 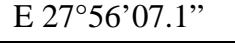 & 2.00 \\
\hline L4_21.07.12 & Lake Jigara & 21.07.2012 & 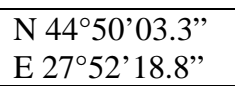 & 1.50 \\
\hline L5_13.06.12 & \multirow{2}{*}{ Lake Curcubeu } & 13.06 .2012 & N 445ํ'09.5” & 0.65 \\
\hline L5_22.06.13 & & 22.06 .2013 & 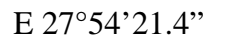 & 2.00 \\
\hline L6_13.06.12 & Lake Gâsca & 13.06.2012 & 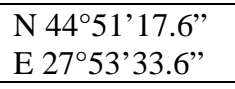 & 0.70 \\
\hline L7_20.07.12 & Lake Cortele & 20.07.2012 & 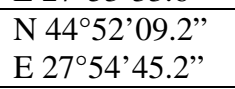 & 1.30 \\
\hline L8_15.06.12 & Lake Cucova & 15.06.2012 & 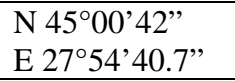 & 1.00 \\
\hline L9_29.04.13 & Lake Lupu & 29.04.2013 & 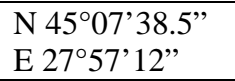 & 3.50 \\
\hline L10_26.09.12 & \multirow{2}{*}{ Lake Bordeiele } & 26.09 .2012 & N 4510'13.2” & 0.30 \\
\hline L10_28.04.13 & & 28.04 .2013 & E $27^{\circ} 58^{\prime} 04.1^{\prime \prime}$ & 3.80 \\
\hline L11_27.04.13 & Lake Stan & 27.04.2013 & $\begin{array}{l}\text { N 4510'40.6”' } \\
\text { E 2758'19.5” }\end{array}$ & 3.00 \\
\hline L12_28.04.13 & $\begin{array}{l}\text { Lake Iezerul } \\
\text { Morilor }\end{array}$ & 28.04.2013 & 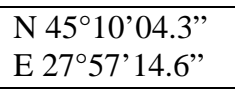 & 2.50 \\
\hline L13_27.04.13 & Lake Chiriloaia & 27.04.2013 & 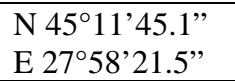 & 3.00 \\
\hline
\end{tabular}

Principal Component Analysis (PCA), one of the most frequently used multivariate data analysis methods (Jolliffe, 2002), was performed in order to visualize the sampling sites depending on several variables: water temperature, dissolved oxygen, $\mathrm{pH}$, maximum depth and the Danube River discharge values.

The non-parametric Mann-Whitney test (Lehmann, 1975) was used to determine if the algal species richness differed in the lakes sampled in 2012 compared to those sampled in 2013. The similarity between the algal communities from the sampling sites was calculated using the Jaccard index (Washington, 1984), which only uses qualitative data (presence/absence of the taxon).

Several trophicity and organic pollution indices based on phytoplankton community were considered (Willén, 2000). The first one, the trophic index according to Heinonen (1980) is calculated as the ratio between the number of species indicating eutrophic conditions and the number of species indicating oligotrophic conditions. Values lower than eight indicate oligotrophic waters. The second trophicity index, the compound index, represents the number of species of Cyanoprokaryota, Chlorococcales, Centrales and Euglenophyta divided by the number of species belonging to Order Desmidiales (Nygaard, 1949). Values below one indicate oligotrophic conditions, values between one and three mesotrophic conditions and values exceeding three eutrophic conditions. The organic pollution index calculated at the genus level (Palmer, 1969) represents the sum of the indicator values of the genera tolerant to organic load. Values not exceeding 15 indicate low organic pollution; values between 15 and 19 indicate moderate pollution and values greater than 20 represent high organic pollution. 
Statistical analyses were performed using PAST software version 2.14-2012 and XLSTAT software - evaluation version 2013.5.

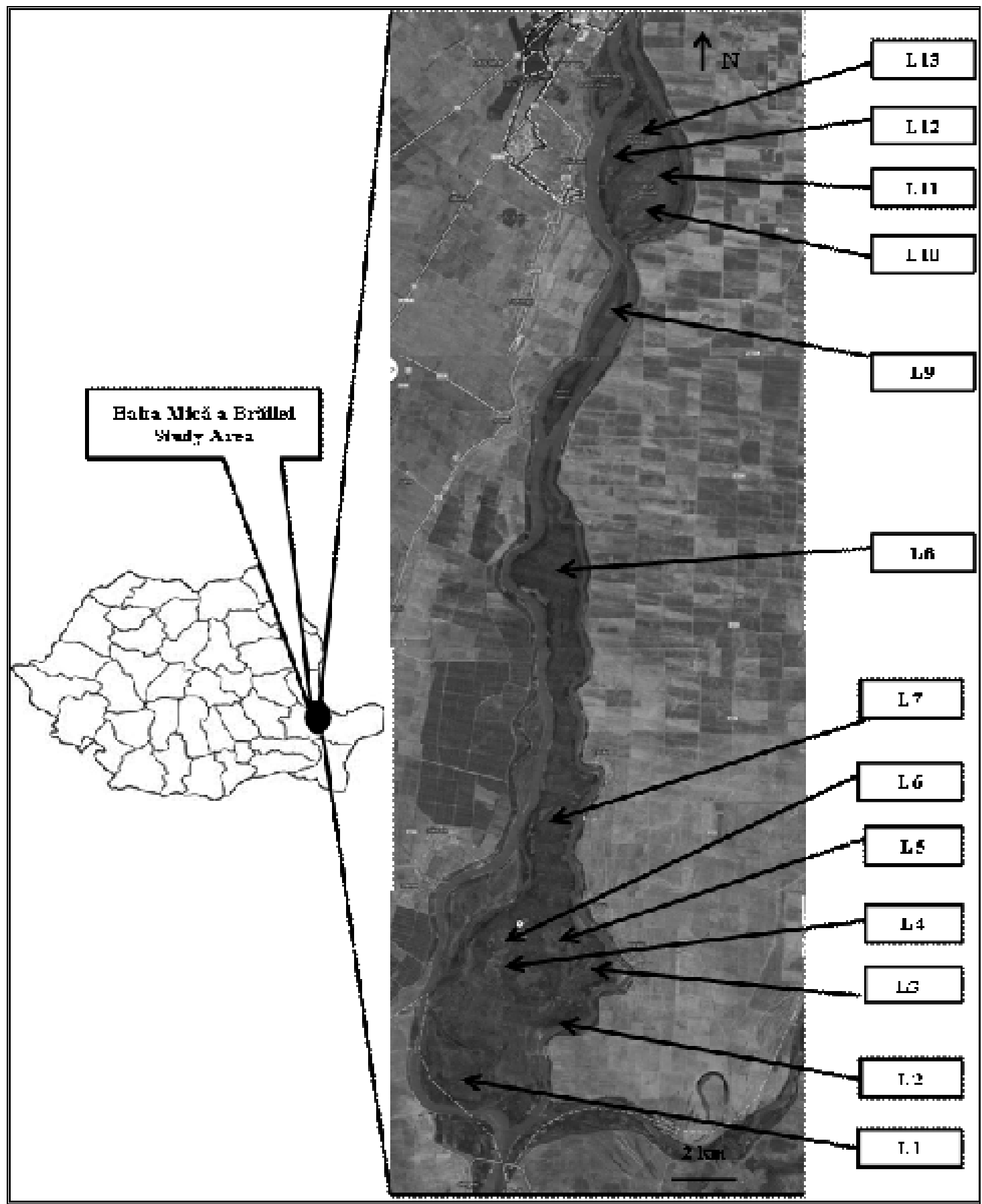

Figure 1: Location of the 13 floodplain lakes from the Balta Mică a Brăilei Nature Park, considered for this study (abbreviation of the sampling sites and occasions as in table 1) (Google Earth, 2013). 


\section{RESULTS AND DISCUSSIONS \\ Physico-chemical factors}

The main physical and chemical parameters were recorded at each site (Tab. 2). pH values were circum-neutral, typical for most surface freshwater systems. Water temperatures recorded normal variations, higher in summer and lower in spring. The quantity of oxygen dissolved in water, on the other hand, was more variable, ranging from minimum values of three or four $\mathrm{mg} / \mathrm{L}$ in small, shaded lakes (L7 - lake Cortele and L1 - lake Japșa), to maximum values of 10 or $11 \mathrm{mg} / \mathrm{L}$ caused by lower temperatures and spring mixing, in the sites sampled in April 2013.

The sampling lakes from Balta Mică a Brăilei Nature Park were aggregated in the Principal Component Analysis (PCA) biplot based on five physical and chemical parameters: the water temperature, maximum depth measured in situ, the Danube mean water discharge recorded in the sampling months at Vadu Oii (Constanța County), dissolved oxygen and the $\mathrm{pH}$ (Fig. 2). Three groups were distinguished on axis F1, based on the first three parameters: 1) one including the lakes with maximum depth, high discharge, but low water temperatures, sampled in April 2013 (left in Fig. 2); 2) the second one including the lakes with minimum depth, low discharge, but high water temperatures, sampled in June, July and September 2012 (right in Fig. 2); and 3) the third one (middle in Fig. 2) with intermediate values.

\section{Species richness}

The algal communities recorded a heterogeneous structure, with planktonic and benthic taxa, which represented a typical situation for shallow floodplain lakes (Bellinger and Sigee, 2010). A total number of 315 algal taxa from seven phyla were identified in the sampling sites. Chlorophyta (green algae) was the dominant phylum, with $42 \%$ of all taxa, followed by Bacillariophyta (28\%), Euglenophyta (20\%), Cyanophyta (6\%) and Xanthophyta, Chrysophyta and Dinophyta, each with less than 2\% (Tab. 3).

In fact, most freshwater shallow lakes are dominated by green algae and diatoms, with the first usually peaking in summer and the latter in spring and autumn (Bellinger and Sigee, 2010). However, in the Danube Delta, similar floodplain lakes located less than $150 \mathrm{~km}$ away from Balta Mică a Brăilei Nature Park in straight line show a slightly different hierarchy of the dominant algal phyla in terms of species number: Bacillariophyta was the most numerous group, followed by Chlorophyta and Cyanophyta (Török, 2011). This difference was caused by the fact that no running waters, usually dominated by diatoms, were sampled in the present paper.

Most of the sampled Chlorophyta taxa were planktonic, since only 17 out of the total number of 135 were true benthic species. However, in the lakes sampled in April and June 2013, during the river floods, green algae recorded a minimum number of species, ranging between one and six, because of their incapacity to remain in the water column during floods.

Diatoms dominated the algal communities from the lakes sampled during the spring floods, in April 2013, as number of taxa. The presence and composition of epiphytic diatom communities are used to detect floods in sediment records (Wiklund et al., 2010). The majority of diatom species from Balta Mică a Brăilei Nature Park was represented by forms attached to substratum, since only 20 out of the total number of 87 diatom species were true planktonic. For example, in lake Chiriloaia (L13_27.04.13), 23 out of 29 diatom taxa were benthic, so they could be either brought by the Danube, or taken from the lake sediment due to the flood.

In contrast, Euglenoids were absent from the lakes sampled in April 2013, due to the high water volume and high water current that made their survival in the water column impossible. This absence could be also explained by the lower levels of organic matter present in the water, caused by the spring floods. 
Similarly, a low number of Cyanophyta species was in April 2013, caused also by increases in water level, a similar situation to that cited in Mihaljević and Stević (2011).

Eleven algal taxa were listed for the first time in Romania: Coccomonas elliptica, Coccomonas platyformis, Euglena obtusa, Goniochloris spinosa, Phacus agilis var. inversa, Phacus asymmetricus, Phacus sesquitortus, Scenedesmus lefevre var. manguinii, Staurastrum paradoxum var. reductum, Trachelomonas wislouchii and Trachelomonas woycickii. Most of these species were identified in lake Sbenghiosu (L2_19.07.12), probably because of the diversity of sampled microhabitats: both open water and shallow regions with macrophytes.

Table 2: Physical and chemical parameters measured in Balta Mică a Brăilei Nature Park (abbreviation of the sampling sites and occasions as in table 1).

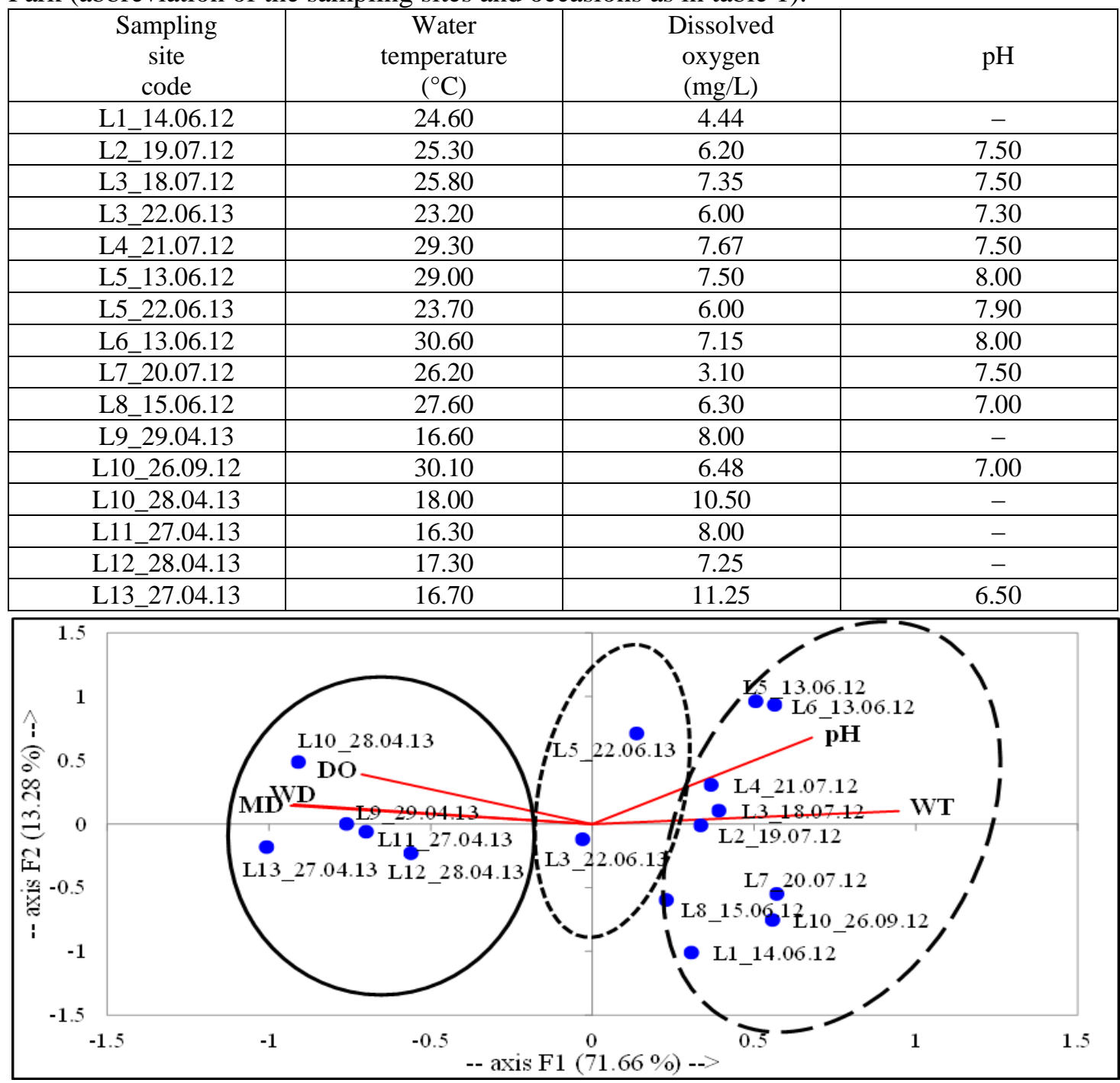

Figure 2: Principal Component Analysis (PCA) biplot of the sampling sites and their aggregation based on: dissolved oxygen - DO (mg/L); maximum depth measured in situ - MD (m); the $\mathrm{pH}$; the Danube mean water discharge recorded in the sampling months at Vadu Oii,

Constanța County - WD $\left(\mathrm{m}^{3} / \mathrm{sec}\right.$.) and the water temperature - WT $\left({ }^{\circ} \mathrm{C}\right)$

(abbreviation of the sampling sites and occasions as in table 1) (axes F1 and F2: 84.94\%). 
Table 3: List of algal taxa identified in the 13 floodplain lakes from Balta Mică a Brăilei area in 2012-2013 (1: L1_14.06.12; 2: L2_19.07.12; 3: L3_18.07.12 and L3_22.06.13; 4: L4_21.07.12; 5: L5_13.06.12 and L5_22.06.13; 6: L6_13.06.12; 7: L7_20.07.12; 8: L8_15.06.12; 9: L9_29.04.13; 10: L10_26.09.12 and L10_28.04.13; 11: L11_27.04.13; 12: L12_28.04.13; 13: L13_27.04.13; abbreviation of sampling sites and occasions as in table 1).

\begin{tabular}{|c|c|c|c|c|c|c|c|c|c|c|c|c|c|}
\hline SAMPLING SITES $(\rightarrow)$ /ALGAL TAXA $(\downarrow)$ & & 2 & 3 & 4 & 5 & 6 & 7 & 8 & 9 & 10 & 11 & 12 & 13 \\
\hline \multicolumn{14}{|l|}{ Phyllum Cyanophyta (Cyanoprokaryota) } \\
\hline Anabaena elliptica Lemmermann, 1898 & & & + & & + & & & & & & & & \\
\hline $\begin{array}{l}\text { Anabaena flos-quae rébisson ex Bornet and } \\
\text { Flauhault, } 1886\end{array}$ & & & & & & + & & & & & & & \\
\hline Anabaena variabilis Kützing, 1843 & + & + & + & + & + & + & + & + & & + & & & \\
\hline $\begin{array}{l}\text { Arthrospira jenneri } \\
\text { Stizenberger ex Gomont, } 1892\end{array}$ & & + & & & & & + & & & & & & \\
\hline Lyngbya kuetzingii Schmidle, 1897 & & & & & & & & + & & & & & \\
\hline $\begin{array}{l}\text { Merismopedia glauca } \\
\text { (Ehrenberg) Kützing, } 1845\end{array}$ & & + & & & + & & & & & & & & \\
\hline Merismopedia tenuissima Lemmermann, 1898 & & + & & & & & & & & & & & \\
\hline Oscillatoria agardhii Gomont, 1892 & & & & & & & + & & & & & & \\
\hline Oscillatoria amphibia Agardh C., 1827 & & + & & + & & & & & & + & & & \\
\hline $\begin{array}{l}\text { Oscillatoria formosa } \\
\text { Bory de Saint-Vincent ex Gomont, } 1892\end{array}$ & & & & & & & & & & & & + & \\
\hline Oscillatoria limnetica Lemmermann, 1900 & & & & & + & & & & + & + & & & \\
\hline Oscillatoria limosa Agardh C., 1812 & & & & & + & & & & & + & & & \\
\hline Oscillatoria planctonica Woloszynska 1912 & & & & + & & & & & & & & & \\
\hline Oscillatoria tenuis Agardh C., 1892 & + & + & + & & + & & & & & & + & + & \\
\hline Oscillatoria utermoehliana Elenkin, 1949 & & & & & & & & & & + & & & \\
\hline Phormidium molle Gomont, 1892 & & & & & & & & + & & & & & \\
\hline $\begin{array}{l}\text { Snowella lacustris } \\
\text { (Chodat) Komárek and Hindák, } 1988\end{array}$ & & & & & + & + & & & & & & & \\
\hline Phyllum Euglenophyta & & & & & & & & & & & & & \\
\hline Euglena acus (Müller O. F.) Ehrenberg, 1830 & + & + & + & + & + & + & + & + & + & & & & \\
\hline Euglena agilis Carter H. J., 1856 & & & & & & & & + & & + & & & \\
\hline Euglena caudata Hübner, 1886 & & & & & & & & + & & & & & \\
\hline Euglena charkowiensis Svirenko D. O., 1913 & & & & & & & + & + & & & & & \\
\hline Euglena contabrica Pringsheim E. G., 1956 & & & & & & & & + & & & & & \\
\hline Euglena cuneata Pringsheim E. G., 1956 & & & & + & + & & & + & & & & & \\
\hline Euglena deses Ehrenberg, 1834 & & & & & & & + & & & + & & & \\
\hline Euglena deses f. intermedia Klebs G. A., 1883 & & + & & & & & & & & & & & \\
\hline Euglena ehrenbergii Klebs G. A., 1883 & & + & & & & + & + & & & + & & & \\
\hline Euglena gracilis Klebs G. A., 1883 & & & & & & & & + & & & & & \\
\hline Euglena limnophila Lemmermann, 1898 & & & & & & & + & + & & & & & \\
\hline Euglena oblonga Schmitz F., 1884 & & & & & & & & + & & + & & & \\
\hline Euglena obtusa Van Goor, 1925 & & & & & & & & + & & & & & \\
\hline Euglena oxyuris Schmarda, 1846 & & + & + & & + & & & & & & & & \\
\hline Euglena proxima Dangeard P. A., 1901 & + & & & & + & & & & + & & & & \\
\hline Euglena repulsans Schiller J., 1952 & + & & & & & & & & & & & & \\
\hline Euglena spathirhyncha Skuja, 1948 & & + & & & & & & & & & & & \\
\hline
\end{tabular}


Table 3 (continued): List of algal taxa identified in the 13 floodplain lakes from Balta Mică a Brăilei area in 2012-2013 (1: L1_14.06.12; 2: L2_19.07.12; 3: L3_18.07.12 and L3_22.06.13; 4: L4_21.07.12; 5: L5_13.06.12 and L5_22.06.13; 6: L6_13.06.12; 7: L7_20.07.12; 8: L8_15.06.12; 9: L9_29.04.13; 10: L10_26.09.12 and L10_28.04.13; 11: L11_27.04.13; 12: L12_28.04.13; 13: L13_27.04.13; abbreviation of the sampling sites and occasions as in table 1).

\begin{tabular}{|c|c|c|c|c|c|c|c|c|c|c|c|}
\hline Euglena spirogyra Ehrenberg, 1832 & + & + & & & + & & & & & & \\
\hline Euglena texta (Dujardin) Hübner, 1886 & + & + & + & & + & + & & & & & \\
\hline Euglena tripteris (Dujardin) Klebs G. A., 1883 & & + & & & + & & & & & & \\
\hline Euglena variabilis Klebs G. A., 1883 & & & & & & & & + & + & & \\
\hline Euglena velata Klebs G. A., 1883 & & & & & & & + & & & & \\
\hline $\begin{array}{l}\text { Euglena viridis (Müller O. F.) Ehrenberg, } \\
1830\end{array}$ & & + & & + & & & & & & & \\
\hline Lepocinclis marssonii Lemmermann, 1904 & & + & & & & & & & & & \\
\hline Lepocinclis ovum Lemmermann, 1901 & & + & + & + & & & & & + & & \\
\hline Phacus acuminatus Stokes, 1885 & & & & + & & & + & + & & & \\
\hline Phacus agilis Skuja, 1926 & & & + & + & & & + & & & & \\
\hline Phacus agilis var. inversa Bourrelly P., 1947 & & + & & & & & & & & & \\
\hline Phacus alatus Klebs G. A., 1886 & + & & & & & & & & & & \\
\hline $\begin{array}{l}\text { Phacus anomalus Fritsch F. E. and Rich M. F., } \\
1929\end{array}$ & & & & + & & & & & + & & \\
\hline Phacus asymmetricus Prescott, 1944 & & & + & & & & & & & & \\
\hline Phacus cochleatus Pochmann, 1942 & + & & & & & & & & & & \\
\hline Phacus glaber (Deflandre) Pochmann, 1931 & & + & & & & & & & + & & \\
\hline Phacus helicoides Pochmann, 1948 & & + & & & & & & & & & \\
\hline $\begin{array}{l}\text { Phacus hispidulus } \\
\text { (Eichwald) Lemmermann, } 1910\end{array}$ & & + & & + & & & & & & & \\
\hline Phacus longicauda Dujardin, 1841 & & + & + & & & & + & & & + & \\
\hline Phacus monilatus Stokes, 1910 & & + & & & & & & & & & \\
\hline Phacus nordstedtii Lemmermann, 1904 & & + & & & & & & & & & \\
\hline Phacus orbicularis Hübner K., 1886 & + & & + & & + & & & & & & \\
\hline Phacus parvulus Klebs G. A., 1883 & & & & & & & + & & & & \\
\hline $\begin{array}{l}\text { Phacus pleuronectes } \\
\text { (Müller O. F.) Nitzsch ex Dujardin, } 1841\end{array}$ & & & + & & + & & & & & & \\
\hline Phacus pyrum (Ehrenberg) Archer W., 1871 & & & & + & & & & & & & \\
\hline Phacus sesquitortus Pochmann, 1942 & & & + & & & & & & & & \\
\hline Phacus suecicus Lemmermann, 1904 & & & & & & & + & & & & \\
\hline Phacus tortus (Lemmermann) Skvortzov, 1928 & + & + & & & + & & & & & & + \\
\hline Phacus trypanon Pochmann, 1942 & & + & & & & & & & & & \\
\hline $\begin{array}{l}\text { Strombomonas acuminata } \\
\text { (Schmarda) Deflandre, } 1930\end{array}$ & & + & & + & + & & & + & & & \\
\hline $\begin{array}{l}\text { Strombomonas deflandrei } \\
\text { (Roll Y. V.) Deflandre, } 1930\end{array}$ & & & & & + & & & & & & \\
\hline Trachelomonas abrupta Svirenko, 1914 & + & & & & & & & & & & \\
\hline Trachelomonas armata Stein F., 1878 & + & + & + & & + & + & & + & + & & \\
\hline Trachelomonas bacillifera Playfair, 1915 & & & & & + & & & & & & \\
\hline Trachelomonas caudata Stein, 1878 & & & & & & & & + & & & \\
\hline Trachelomonas hexangulata Svirenko, 1914 & & + & & & & & & & & & \\
\hline Trachelomonas hispida (Perty) Stein F. 1878 & & + & + & + & + & + & & + & + & & \\
\hline
\end{tabular}


Table 3 (continued): List of algal taxa identified in the 13 floodplain lakes from Balta Mică a Brăilei area in 2012-2013 (1: L1_14.06.12; 2: L2_19.07.12; 3: L3_18.07.12 and L3_22.06.13; 4: L4_21.07.12; 5: L5_13.06.12 and L5_22.06.13; 6: L6_13.06.12; 7: L7_20.07.12; 8: L8_15.06.12; 9: L9_29.04.13; 10: L10_26.09.12 and L10_28.04.13; 11: L11_27.04.13; 12: L12_28.04.13; 13: L13_27.04.13; abbreviation of the sampling sites and occasions as in table 1).

\begin{tabular}{|c|c|c|c|c|c|c|c|c|c|c|c|c|c|}
\hline Trachelomonas intermedia Dangeard P. A., 1902 & + & & & & & & & & & & & & \\
\hline Trachelomonas oblonga Lemmermann, 1899 & & & & & & & + & + & & & & & \\
\hline Trachelomonas planctonica Svirenko, 1914 & & & & & & & + & & & & & & \\
\hline Trachelomonas pulcherrima Playfair, 1915 & & & & & & & & & & + & & & \\
\hline Trachelomonas scabra Playfair, 1915 & & & & + & & & & & & & & & \\
\hline Trachelomonas verrucosa Stokes A., 1887 & & + & & & & & & & & & & & \\
\hline $\begin{array}{l}\text { Trachelomonas volvocina } \\
\text { (Ehrenberg) Ehrenberg, } 1834\end{array}$ & & & & + & & & + & + & & + & & & \\
\hline Trachelomonas volvocinopsis Svirenko, 1914 & & + & + & & + & + & & & & & & & \\
\hline Trachelomonas wislouchii Skvortzov, 1917 & & + & + & & & & & & & & & & \\
\hline Trachelomonas woycickii Koczwara, 1914 & & + & & & & & & & & & & & \\
\hline \multicolumn{14}{|l|}{ Phyllum Dinophyta } \\
\hline Gymnodinium paradoxum Schilling A. J., 1891 & & & & & & & & + & & + & & & \\
\hline Peridinium aciculiferum Lemmermann, 1900 & & & & & & + & & & & & & & \\
\hline $\begin{array}{l}\text { Peridinium cinctum } \\
\text { (Müller O. F.) Ehrenberg, } 1832\end{array}$ & & & & & & & & + & & & & & \\
\hline \multicolumn{14}{|l|}{ Phyllum Chrysophyta } \\
\hline Chrysococcus rufescens Klebs, 1893 & & & & & & & + & + & & & & & \\
\hline Dinobryon bavaricum Imhof, 1890 & & & & & & + & & & & & & & \\
\hline Dinobryon cylindricum Imhof O. E., 1887 & & & & & & & & + & & & & & \\
\hline Dinobryon sertularia Ehrenberg, 1834 & & & + & & + & + & & & & + & + & + & \\
\hline \multicolumn{14}{|l|}{ Phyllum Bacillariophyta } \\
\hline Achnanthes bioretii Germain, 1957 & + & & & & & & & & & & & & \\
\hline $\begin{array}{l}\text { Achnanthes helvetica } \\
\text { (Hustedt) Lange-Bertalot, } 1989\end{array}$ & & & & & & & & & & + & & & \\
\hline $\begin{array}{l}\text { Achnanthes hungarica (Grunow) Grunow in } \\
\text { Cleve and Grunow, } 1880\end{array}$ & & + & + & & & & & & & & & & \\
\hline Achnanthes lanceolata van Heurck H., 1880 & & + & + & & & & & & & & & & + \\
\hline Achnanthes minutissima Kützing, 1833 & & & + & & & & & & & + & & & \\
\hline Amphora libyca Ehrenberg, 1840 & & & + & & & & & & & + & & & + \\
\hline Amphora ovalis (Kützing) Kützing, 1844 & & & & & & & & & & & & + & \\
\hline $\begin{array}{l}\text { Amphora pediculus } \\
\text { (Kützing) Grunow ex Schmidt A., } 1875\end{array}$ & + & + & + & & + & & + & + & & + & & & \\
\hline Amphora veneta Kützing, 1844 & + & + & & & + & + & + & & & + & & & + \\
\hline Anomoeoneis sphaerophora Pfitzer E., 1871 & & & & + & & & & + & & & & & \\
\hline Asterionella formosa Hassall, 1850 & & & & & & & & & + & + & + & & + \\
\hline $\begin{array}{l}\text { Aulacoseira granulata } \\
\text { (Ehrenberg) Simonsen, } 1979\end{array}$ & & + & & + & & + & & & + & & & & \\
\hline Caloneis silicula (Ehrenberg) Cleve, 1894 & & + & + & + & & + & & + & & + & & & \\
\hline Cocconeis pediculus Ehrenberg, 1838 & & + & & & & & & & & & & & \\
\hline Cocconeis placentula Ehrenberg, 1838 & & & & & & & & & & + & & & \\
\hline Cyclotella atomus Hustedt, 1937 & & & & & & & & & & & & + & \\
\hline
\end{tabular}


Table 3 (continued): List of algal taxa identified in the 13 floodplain lakes from Balta Mică a Brăilei area in 2012-2013 (1: L1_14.06.12; 2: L2_19.07.12; 3: L3_18.07.12 and L3_22.06.13; 4: L4_21.07.12; 5: L5_13.06.12 and L5_22.06.13; 6: L6_13.06.12; 7: L7_20.07.12; 8: L8_15.06.12; 9: L9_29.04.13; 10: L10_26.09.12 and L10_28.04.13; 11: L11_27.04.13; 12: L12_28.04.13; 13: L13_27.04.13; abbreviation of the sampling sites and occasions as in table 1 ).

\begin{tabular}{|c|c|c|c|c|c|c|c|c|c|c|c|c|c|}
\hline $\begin{array}{l}\text { Trachelomonas intermedia Dangeard P. A., } \\
1902\end{array}$ & + & & & & + & & & & & & & & \\
\hline Trachelomonas oblonga Lemmermann, 1899 & + & + & & & & & & + & & + & & & \\
\hline Trachelomonas planctonica Svirenko, 1914 & & & & & & & & & + & + & & + & + \\
\hline Trachelomonas pulcherrima Playfair, 1915 & + & & & & & & & & & & & & \\
\hline Trachelomonas scabra Playfair, 1915 & + & + & + & & & + & & & + & + & & & \\
\hline Trachelomonas verrucosa Stokes A., 1887 & & & & & & & & & & & & & + \\
\hline $\begin{array}{l}\text { Trachelomonas volvocina } \\
\text { (Ehrenberg) Ehrenberg, } 1834\end{array}$ & & & & & & & & & & & & & + \\
\hline Trachelomonas volvocinopsis Svirenko, 1914 & & & & & & & & & + & & & + & \\
\hline Trachelomonas wislouchii Skvortzov, 1917 & & + & & & + & + & & & & & + & & + \\
\hline Trachelomonas woycickii Koczwara, 1914 & & & & & & & & & & + & & & \\
\hline Phyllum Dinophyta & & & & & & & & & & + & & & \\
\hline Gymnodinium paradoxum Schilling A. J., 1891 & & & & & & & & & & + & & + & + \\
\hline Peridinium aciculiferum Lemmermann, 1900 & & & & & & & & & & + & & & \\
\hline $\begin{array}{l}\text { Peridinium cinctum } \\
\text { (Müller O. F.) Ehrenberg, } 1832\end{array}$ & & & & & + & + & & & & & & + & + \\
\hline Phyllum Chrysophyta & + & & & + & & & + & & & + & & & \\
\hline Chrysococcus rufescens Klebs, 1893 & & + & & & + & + & & & & & & & \\
\hline Dinobryon bavaricum Imhof, 1890 & & & & & + & & & + & & + & & & \\
\hline Dinobryon cylindricum Imhof O. E., 1887 & & & & & & & + & + & & & & & \\
\hline Dinobryon sertularia Ehrenberg, 1834 & & & & & & & & & & & + & & + \\
\hline Phyllum Bacillariophyta & + & & & & & & + & & & & & & + \\
\hline Achnanthes bioretii Germain, 1957 & & & + & & & & & & & & & & \\
\hline $\begin{array}{l}\text { Achnanthes Helvetica } \\
\text { (Hustedt) Lange-Bertalot, } 1989\end{array}$ & & & & & & & & & & & & + & \\
\hline $\begin{array}{l}\text { Achnanthes hungarica (Grunow) Grunow in } \\
\text { Cleve and Grunow, } 1880\end{array}$ & & & + & & + & & & & + & & + & + & + \\
\hline Achnanthes lanceolata van Heurck H. (1880) & + & + & + & & & & + & & + & + & + & & + \\
\hline Achnanthes minutissima Kützing, 1833 & + & & & & & & & & & & & & \\
\hline Amphora libyca Ehrenberg, 1840 & & & & & & & & & & + & & & + \\
\hline Amphora ovalis (Kützing) Kützing 1844 & & & + & & + & & & & + & + & & & \\
\hline $\begin{array}{l}\text { Amphora pediculus } \\
\text { (Kützing) Grunow ex Schmidt A., } 1875\end{array}$ & & & + & & & & & & & & & & \\
\hline Amphora veneta Kützing, 1844 & & & & & & & & & & + & & & + \\
\hline Anomoeoneis sphaerophora Pfitzer E., 1871 & + & + & & + & + & + & + & & & + & + & & + \\
\hline Asterionella formosa Hassall, 1850 & & & + & & & & & & & & & & \\
\hline Cyclotella atomus Hustedt, 1937 & & & & & & & & & & + & & & \\
\hline
\end{tabular}


Table 3 (continued): List of algal taxa identified in the 13 floodplain lakes from Balta Mică a Brăilei area in 2012-2013 (1: L1_14.06.12; 2: L2_19.07.12; 3: L3_18.07.12 and L3_22.06.13; 4: L4_21.07.12; 5: L5_13.06.12 and L5_22.06.13; 6: L6_13.06.12; 7: L7_20.07.12; 8: L8_15.06.12; 9: L9_29.04.13; 10: L10_26.09.12 and L10_28.04.13; 11: L11_27.04.13; 12: L12_28.04.13; 13: L13_27.04.13; abbreviation of the sampling sites and occasions as in table 1).

\begin{tabular}{|c|c|c|c|c|c|c|c|c|c|c|c|c|c|}
\hline $\begin{array}{l}\text { Cyclotella cyclopunctata } \\
\text { Håkansson and Carter J. R., } 1990\end{array}$ & & & & & & & & & + & + & + & + & + \\
\hline Cyclotella distinguenda Hustedt, 1928 & & & & & & & & & & + & & & \\
\hline Cyclotella meneghiniana Kützing, 1844 & + & & & & & + & & & & + & & + & + \\
\hline Cyclotella pseudostelligera Hustedt, 1939 & + & & + & & & + & & & & + & & & + \\
\hline Cymatopleura solea (Brébisson) Smith, 1851 & & + & & & & & & & & & & & \\
\hline Cymbella affinis Kützing, 1844 & + & + & & & & & + & & & & & & \\
\hline Cymbella aspera (Ehrenberg) Cleve, 1894 & & + & & & & & & + & & & & & \\
\hline Cymbella helvetica Kützing, 1844 & + & + & + & & & & & & & & & & \\
\hline Cymbella minuta Hilse in Rabenhorst, 1862 & & + & & & & & & & & + & & & \\
\hline $\begin{array}{l}\text { Cymbella simonsenii } \\
\text { Krammer in Krammer and Lange, } 1985\end{array}$ & & & & & & & & & + & & & & \\
\hline Cymbella tumida van Heurck, 1880 & & + & & & & & + & + & & & & & + \\
\hline $\begin{array}{l}\text { Diatoma monoliformis } \\
\text { (Kützing) Williams D. M., } 2012\end{array}$ & + & & & & & & & & & & & & \\
\hline Diatoma tenuis Agardh C., 1812 & & & & & + & & & & & & & & \\
\hline Diatoma vulgaris Bory de Saint-Vincent, 1824 & + & & & & & & & & & & & & \\
\hline $\begin{array}{l}\text { Didymosphenia geminata (Lyngbye) Schmidt } \\
\text { M. in Schmidt A., } 1899\end{array}$ & & & & & & & + & & & + & & & + \\
\hline Diploneis eliptica (Kützing) Cleve, 1894 & & + & & & & & & & & & & & \\
\hline Epithemia adnata (Kützing) Brébisson, 1838 & & & & & & & & & & + & & & \\
\hline Fragilaria capucina Desmazières, 1830 & & + & & & & & & & & & & & \\
\hline $\begin{array}{l}\text { Fragilaria capucina var. vaucheriae (Kützing) } \\
\text { Lange-Bertalot, } 1980\end{array}$ & + & & & & & & & & & & & & + \\
\hline Fragilaria crotonensis Kitton, 1869 & & & & & & + & & & & + & & & \\
\hline $\begin{array}{l}\text { Fragilaria pulchella } \\
\text { (Ralfs ex Kützing) Lange-Bertalot, } 1980\end{array}$ & & & & & & & + & & & & & & + \\
\hline $\begin{array}{l}\text { Fragilaria tenera } \\
\text { (Smith W.) Lange-Bertalot, } 1980\end{array}$ & & + & & & & & & & & & & & \\
\hline Fragilaria ulna (Nitzsch) Lange, 1980 & & + & + & + & + & + & & + & & & & & \\
\hline $\begin{array}{l}\text { Fragilaria ulna var. acus } \\
\text { (Kützing) Lange-Bertalot, } 1980\end{array}$ & & & & & + & & & & + & & & & \\
\hline Fragilaria bidens Heiberg, 1863 & + & + & & & + & + & & & & & & + & + \\
\hline Gomphonema acuminatum Ehrenberg, 1832 & & & & & & & & & + & & & & \\
\hline Gomphonema augur Ehrenberg, 1840 & + & + & & & & & & & & + & & & \\
\hline Gomphonema clavatum Ehrenberg, 1832 & & + & & & & & + & & & & & & \\
\hline $\begin{array}{l}\text { Gomphonema olivaceum } \\
\text { (Hornemann) Brébisson, } 1838\end{array}$ & & & & & & + & & & & & & & \\
\hline $\begin{array}{l}\text { Gomphonema parvulum } \\
\text { (Kützing) Kützing, } 1849\end{array}$ & & & & & & & & & & & + & & \\
\hline $\begin{array}{l}\text { Gyrosigma acuminatum } \\
\text { (Kützing) Rabenhorst, } 1853\end{array}$ & + & + & + & & + & + & & + & + & & + & + & + \\
\hline
\end{tabular}


Table 3 (continued): List of algal taxa identified in the 13 floodplain lakes from Balta Mică a Brăilei area in 2012-2013 (1: L1_14.06.12; 2: L2_19.07.12; 3: L3_18.07.12 and L3_22.06.13; 4: L4_21.07.12; 5: L5_13.06.12 and L5_22.06.13; 6: L6_13.06.12; 7: L7_20.07.12; 8: L8_15.06.12; 9: L9_29.04.13; 10: L10_26.09.12 and L10_28.04.13; 11: L11_27.04.13; 12: L12_28.04.13; 13: L13_27.04.13; abbreviation of the sampling sites and occasions as in table 1).

\begin{tabular}{|c|c|c|c|c|c|c|c|c|c|c|c|c|}
\hline Melosira varians Agardh C., 1827 & & & & & & & & & + & & & \\
\hline Navicula capitata Ehrenberg, 1838 & & & & & & & & & & & + & + \\
\hline Navicula capitatoradiata Germain, 1981 & + & & & & & & & & & & & \\
\hline $\begin{array}{l}\text { Navicula cincta } \\
\text { (Ehrenberg) Ralfs in Pritchard, } 1861\end{array}$ & & & & & & & + & & & & & + \\
\hline $\begin{array}{l}\text { Navicula cryptotenella Lange-Bertalot in } \\
\text { Krammer and Lange-Bertalot, } 1985\end{array}$ & & & & & & & & + & & + & + & + \\
\hline Navicula cuspidata (Kutzing) Kutzing, 1844 & + & + & + & + & + & + & + & + & + & & & \\
\hline $\begin{array}{l}\text { Navicula cuspidata var. ambigua } \\
\text { (Ehrenberg) Cleve, } 1894\end{array}$ & & & & & & & & & & + & & \\
\hline Navicula decusis Østrup, 1910 & & & & & & & & & & & + & \\
\hline Navicula gregaria Donkin, 1861 & & & & & & & & & & & & \\
\hline Navicula kotschyi Grunow, 1860 & & & & & & & & & & + & & \\
\hline Navicula placentula Kützing, 1844 & & + & + & + & & & + & & & & & \\
\hline Navicula pupula Kützing, 1844 & & & & & & & + & & & & & \\
\hline Navicula pygmaea Kützing, 1849 & & & & & & & + & & & & & \\
\hline $\begin{array}{l}\text { Navicula tripunctata (Müller O. F.) Bory de } \\
\text { Saint-Vincent in Bory de Saint-Vincent, } 1822\end{array}$ & & & & & & & & & + & & & \\
\hline Navicula veneta Kützing, 1844 & & & & & & & & & & & & \\
\hline Navicula viridula (Kützing) Ehrenberg, 1838 & + & + & + & + & + & + & & & + & + & & + \\
\hline Neidium ampliatum (Ehrenberg) Krammer & & & & & & & + & & & & & \\
\hline Nitzschia acicularis (Kützing) Smith W., 1853 & & + & + & & & & + & & + & & & \\
\hline Nitzschia amphibia Grunow, 1862 & & + & + & & & + & & & & & & \\
\hline Nitzschia calida Grunow, 1880 & & & + & + & & + & & & & & & \\
\hline Nitzschia disipata (Kützing) Grunow, 1862 & & & & & & & & + & & & & \\
\hline Nitzschia hungarica Grunow, 1862 & & & & + & & & & & & & & \\
\hline Nitzschia levidensis Grunow in Heurck, 1881 & & & & & + & & & & & & & \\
\hline Nitzschia linearis Smith W., 1853 & & & + & & & & & & & & & \\
\hline Nitzschia palea (Kützing) Smith W., 1856 & & + & + & & & & & & + & & & \\
\hline Nitzschia reversa Smith W., 1853 & & & & & & + & & & & & & \\
\hline $\begin{array}{l}\text { Nitzschia subacicularis } \\
\text { Hustedt in Schmidt et al., } 1922\end{array}$ & & & & & & & & & & & & + \\
\hline $\begin{array}{l}\text { Pinnularia microstauron } \\
\text { (Ehrenberg) Cleve, } 1891\end{array}$ & & & & & + & & & & & & & \\
\hline $\begin{array}{l}\text { Pinnularia rupestris } \\
\text { Hantzsch in Rabenhorst, } 1861\end{array}$ & & & + & & & & & & & & & \\
\hline $\begin{array}{l}\text { Pinnularia viridiformes } \\
\text { Krammer Gaiser and Johansen, } 2000\end{array}$ & & & & + & & & & & & & & \\
\hline Melosira varians Agardh C., 1827 & & + & & & & & & & & & & \\
\hline $\begin{array}{l}\text { Rhoicosphaenia abbreviata } \\
\text { (Agardh C.) Lange-Bertalot, } 1980\end{array}$ & & & & & & & & & & + & & \\
\hline
\end{tabular}


Table 3 (continued): List of algal taxa identified in the 13 floodplain lakes from Balta Mică a Brăilei area in 2012-2013 (1: L1_14.06.12; 2: L2_19.07.12; 3: L3_18.07.12 and L3_22.06.13; 4: L4_21.07.12; 5: L5_13.06.12 and L5_22.06.13; 6: L6_13.06.12; 7: L7_20.07.12; 8: L8_15.06.12; 9: L9_29.04.13; 10: L10_26.09.12 and L10_28.04.13; 11: L11_27.04.13; 12: L12_28.04.13; 13: L13_27.04.13; abbreviation of the sampling sites and occasions as in table 1).

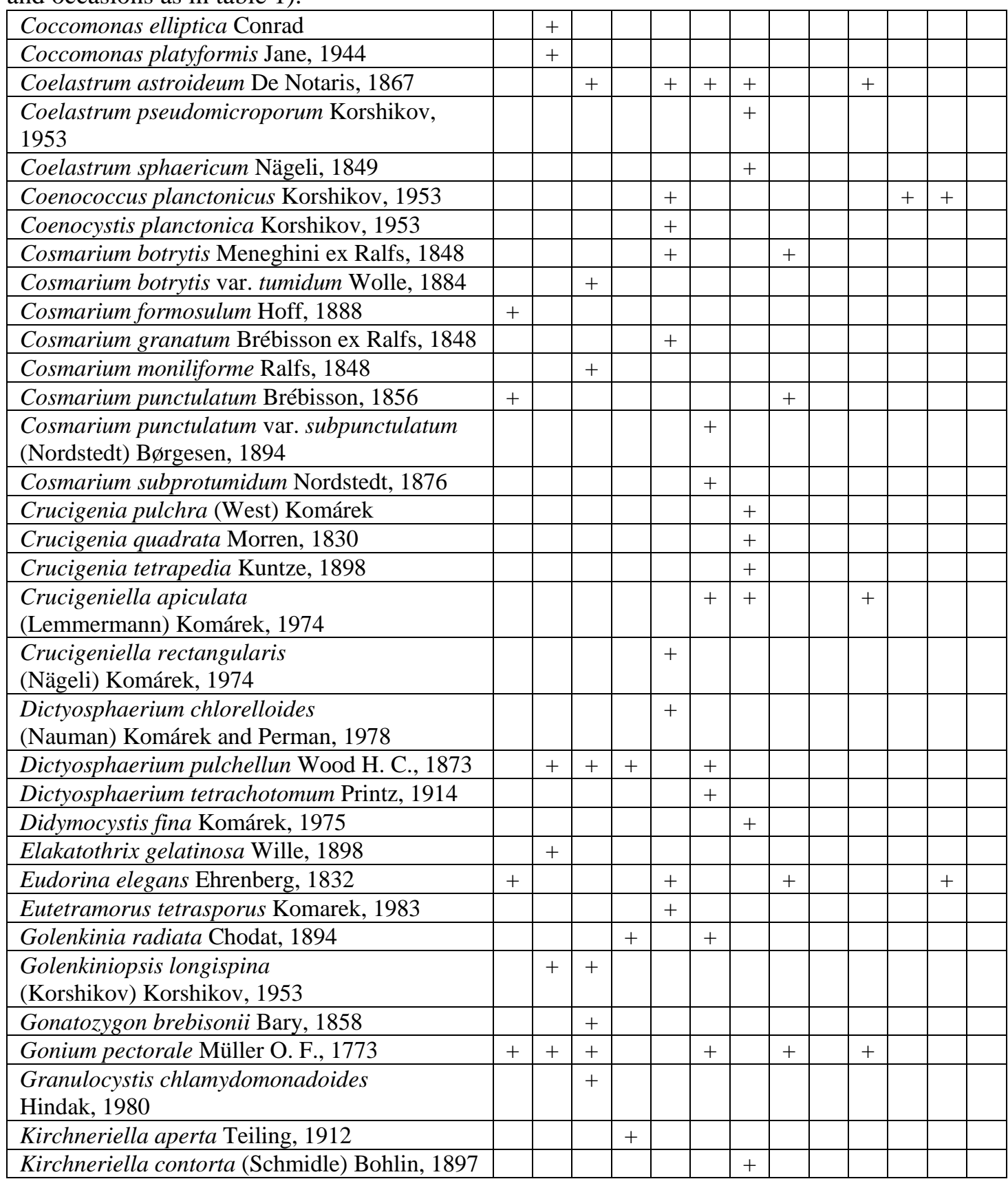


Table 3 (continued): List of algal taxa identified in the 13 floodplain lakes from Balta Mică a Brăilei area in 2012-2013 (1: L1_14.06.12; 2: L2_19.07.12; 3: L3_18.07.12 and L3_22.06.13; 4: L4_21.07.12; 5: L5_13.06.12 and L5_22.06.13; 6: L6_13.06.12; 7: L7_20.07.12; 8: L8_15.06.12; 9: L9_29.04.13; 10: L10_26.09.12 and L10_28.04.13; 11: L11_27.04.13; 12: L12_28.04.13; 13: L13_27.04.13; abbreviation of the sampling sites and occasions as in table 1).

\begin{tabular}{|c|c|c|c|c|c|c|c|c|c|c|c|c|c|}
\hline $\begin{array}{l}\text { Kirchneriella irregularis } \\
\text { (Smith G. M.) Korshikov, } 1953\end{array}$ & & & & & & & + & & & + & & & \\
\hline Kirchneriella lunaris Möbius K., 1894 & & & & & & & & + & & & & & \\
\hline $\begin{array}{l}\text { Kirchneriella obesa } \\
\text { (West) West and West G. S., } 1894\end{array}$ & & & & & & + & & + & & & & & \\
\hline Kirchneriella subcapitata Korshikov, 1953 & & & & & & & + & & & & & & \\
\hline Lagerheimia genevensis Chodat, 1895 & & & & & & + & & & & & & & \\
\hline $\begin{array}{l}\text { Lagerheimia longiseta } \\
\text { (Lemmermann) Printz, } 1914\end{array}$ & & + & & & & & & & & & & & \\
\hline Lagerheimia subsalsa Lemmermann, 1898 & & & & & & + & + & & & & & & \\
\hline Lagerheimia wratislaviensis Schröder, 1897 & & + & & + & & & + & & & & & & \\
\hline Micractinium pusillum Fresenius, 1858 & & & + & + & & & + & & & & & & \\
\hline Micractinium quadrisetum Smith G. M., 1916 & & + & + & & & + & & & & & & & + \\
\hline $\begin{array}{l}\text { Monoraphidium arcuatum } \\
\text { (Korshikov) Hindák, } 1970\end{array}$ & & + & & & & + & + & & & + & & & \\
\hline $\begin{array}{l}\text { Monoraphidium contortum } \\
\text { (Thuret) Komárková-Legnerová in Fott, } 1969\end{array}$ & & + & & + & + & + & + & + & & + & & & \\
\hline $\begin{array}{l}\text { Monoraphidium convolutum } \\
\text { (Corda) Komárková-Legnerová, } 1969\end{array}$ & & & & & & & + & & & & & & \\
\hline $\begin{array}{l}\text { Monoraphidium griffithii } \\
\text { (Berkeley) Komárková-Legnerová, } 1969\end{array}$ & & + & + & + & + & + & & & & + & & & \\
\hline $\begin{array}{l}\text { Monoraphidium irregulare } \\
\text { (Smith G. M.) Komárková-Legnerová, } 1969\end{array}$ & & + & & & & & + & & & & & & \\
\hline $\begin{array}{l}\text { Monoraphidium pusillum } \\
\text { (Printz) Komárková-Legnorová, } 1969\end{array}$ & & & & & & & + & & & & & & \\
\hline Mougeotia sp. Agardh C. A., 1824 & & & & & & & & + & & & & & \\
\hline Nephrocytium agardhianum Nägeli, 1849 & & & & & & + & & & & & & & \\
\hline Oocystis borgei Snow J. W., 1903 & & & & & + & & & & & & & & \\
\hline Oocystis lacustris Chodat, 1897 & & & + & & + & + & + & & & & & & \\
\hline Oocystis marssonii Lemmermann, 1898 & & & & & & + & & & & & & & \\
\hline Oocystis parva West and West G. S., 1898 & & & & & & + & & & & & & & \\
\hline Pandorina charkoviensis Korsch, 1923 & & & + & & & & & & & + & & & \\
\hline $\begin{array}{l}\text { Pandorina morum (Müller O. F.) Bory de } \\
\text { Saint-Vincent in Lamouroux, Bory de Saint- } \\
\text { Vincent and Deslongschamps, } 1824\end{array}$ & + & + & + & + & + & + & & + & + & + & + & + & + \\
\hline Pediastrum boryanum Meneghini, 1840 & & & & & + & & + & & & & + & + & + \\
\hline $\begin{array}{l}\text { Pediastrum boryanum var. cornutum } \\
\text { (Raciborski) Sulek in Fott, } 1969\end{array}$ & + & & & & + & & & & & & & & \\
\hline $\begin{array}{l}\text { Pediastrum boryanum var. longicorne } \\
\text { Reinsch, } 1867\end{array}$ & & & & & & + & & & & + & & & \\
\hline Pediastrum duplex Meyen, 1829 & + & + & + & + & + & + & + & & & + & & & \\
\hline Pediastrum simplex Meyen, 1829 & & & & & & + & + & & & & & & \\
\hline Pediastrum tetras Ralfs, 1845 & & + & + & & + & & + & & & & & & \\
\hline
\end{tabular}


Table 3 (continued): List of algal taxa identified in the 13 floodplain lakes from Balta Mică a Brăilei area in 2012-2013 (1: L1_14.06.12; 2: L2_19.07.12; 3: L3_18.07.12 and L3_22.06.13; 4: L4_21.07.12; 5: L5_13.06.12 and L5_22.06.13; 6: L6_13.06.12; 7: L7_20.07.12; 8: L8_15.06.12; 9: L9_29.04.13; 10: L10_26.09.12 and L10_28.04.13; 11: L11_27.04.13; 12: L12_28.04.13; 13: L13_27.04.13; abbreviation of the sampling sites and occasions as in table 1 ).

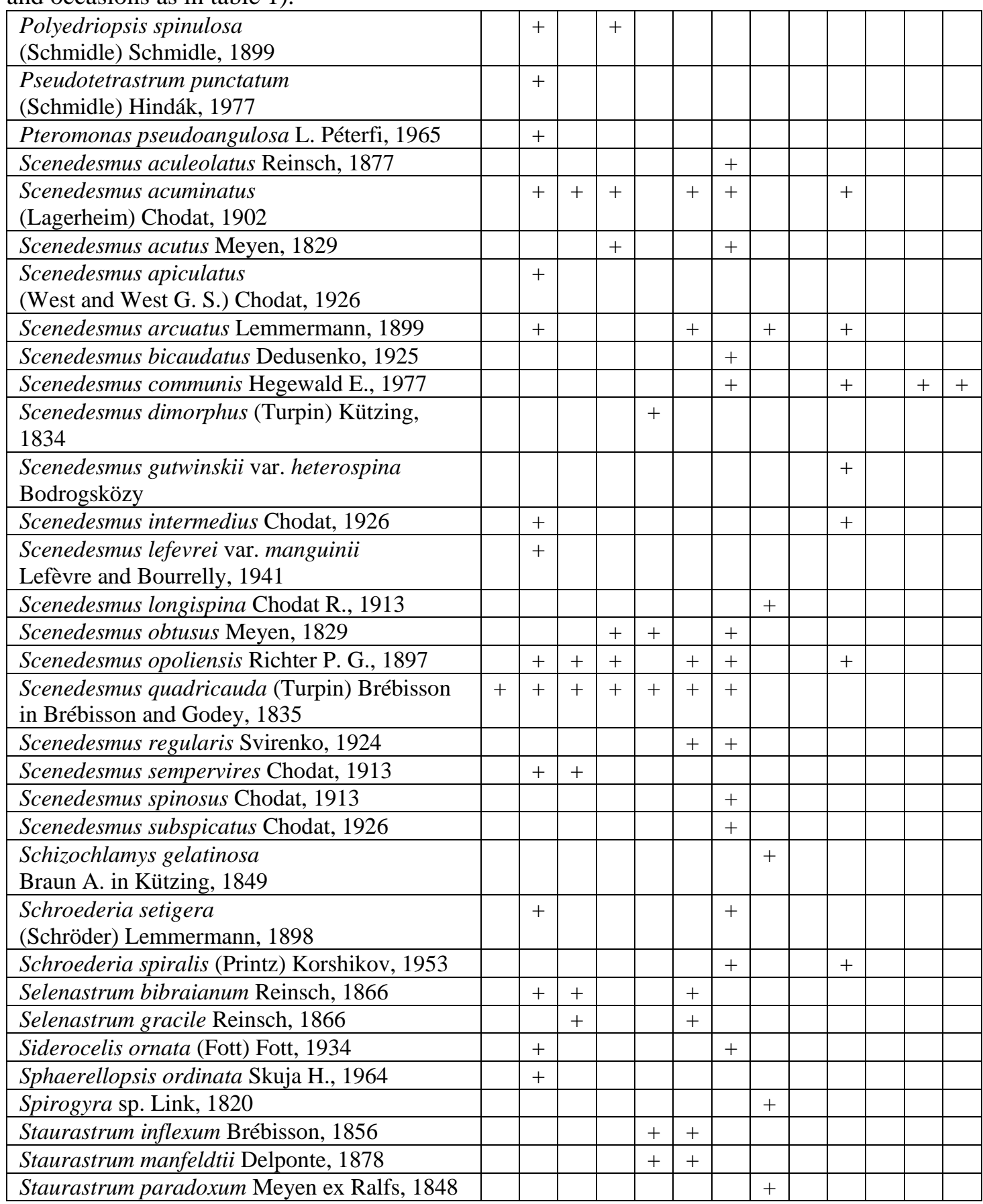


Table 3 (continued): List of algal taxa identified in the 13 floodplain lakes from Balta Mică a Brăilei area in 2012-2013 (1: L1_14.06.12; 2: L2_19.07.12; 3: L3_18.07.12 and L3_22.06.13; 4: L4_21.07.12; 5: L5_13.06.12 and L5_22.06.13; 6: L6_13.06.12; 7: L7_20.07.12; 8: L8_15.06.12; 9: L9_29.04.13; 10: L10_26.09.12 and L10_28.04.13; 11: L11_27.04.13; 12: L12_28.04.13; 13: L13_27.04.13; abbreviation of the sampling sites and occasions as in table 1 ).

\begin{tabular}{|l|l|l|l|l|l|l|l|l|l|l|l|l|l|}
\hline $\begin{array}{l}\text { Staurastrum paradoxum var. reductum } \\
\text { Coesel, 1996 }\end{array}$ & & & & & & + & & & & & & & \\
\hline Stigeoclonium lubricum Kützing, 1845 & & & & & & & & & & & & + & \\
\hline $\begin{array}{l}\text { Temnogametum sinense } \\
\text { Jao C. C. and Hu H. J., 1978 }\end{array}$ & + & & & & & & & & & & & \\
\hline Tetraedron caudatum (Corda) Hansgirg, 1888 & & + & + & & & & + & & & & & & \\
\hline Tetraedron acutum Playfair & & & & & + & & & & & & & & \\
\hline Tetraedron enorme (Ralfs) Hansgirg, 1888 & & + & & & & & & & & & & & \\
\hline Tetraedron limneticum Borge, 1900 & + & & & & & & & & & & & \\
\hline Tetraedron longispinum (Perty) Playfair & + & + & & & & & & & & & & \\
\hline $\begin{array}{l}\text { Tetraedron minimum (Braun A.) Hansgirg, } \\
\text { 1888 }\end{array}$ & + & + & + & & & + & & & + & & & \\
\hline $\begin{array}{l}\text { Tetraedron muticum (Braun A.) Hansgirg, } \\
\text { 1888 }\end{array}$ & & & & & + & & & & & & & & \\
\hline Tetraedron regulare Kützing, 1845 & & + & & & & & & & & & & & \\
\hline Tetraedron triangulare Korshikov, 1953 & & & & & & & & & & + & & & \\
\hline Tetraedron trigonum (Nägeli) Hansgirg, 1888 & & + & & & & & & & & & & & \\
\hline Tetrastrum elegans Playfair, 1917 & & & & & & & + & & & & & & \\
\hline $\begin{array}{l}\text { Tetrastrum heteracanthum } \\
\text { (Nordstedt) Chodat, 1895 }\end{array}$ & & + & & & & & & & & & & & \\
\hline Tetrastrum peterfii Hortobagyi, 1967 & & + & & + & & & & & & & & & \\
\hline $\begin{array}{l}\text { Tetrastrum staurogeniiforme } \\
\text { (Schröder) Lemmermann, 1900 }\end{array}$ & & & & & & & & & & + & & & \\
\hline Tetrastrum triangulare Komárek, 1974 & & + & & & & + & & & & & & \\
\hline $\begin{array}{l}\text { Treubaria setigera (Archer) Smith G. M., } \\
\text { 1933 }\end{array}$ & & & + & & & & & & & & \\
\hline Treubaria triappendiculata Bernard C., 1908 & & & & & & + & & & & & & \\
\hline $\begin{array}{l}\text { Westella botryoides (West) De Wildeman, } \\
\text { 1897 }\end{array}$ & & & & + & + & & + & & & & \\
\hline
\end{tabular}

Lake Sbenghiosu recorded the highest species richness, with a total of 109 taxa (Fig. 3). A higher number of taxa were identified in June, July and September 2012, compared to April and June 2013 (Mann-Whitney test $\mathrm{U}=0 ; \mathrm{p}=0.00017 ; \mathrm{n}_{1}=9 ; \mathrm{n}_{2}=7$ ). This is probably due to the differences in the Danube River discharge from one year to another: in 2013, drastic discharge increases led to a high volume of water entering the floodplain lakes, washing and reducing the algal species number, thus influencing the species richness.

A low similarity was recorded between the algal communities from the 13 sampling sites from Balta Mică a Brăilei Nature Park, even if most of the sampling lakes were located not far away from each other and some were even inter-connected through canals (Fig. 4). The Jaccard similarity percentage did not exceed $30 \%$, probably due to the high diversity of microhabitats characteristic to the 13 sampling lakes, mainly depending on the characteristic macrophytes (submerged, emerged or natant). 
Three clusters were clearly separated, similar to those distinguished in the PCA biplot (Fig. 2): lakes sampled in June 2013, the ones sampled in April 2013 and those sampled in 2012. The only sampling site that did not fit into one of these was lake Japșa - L1 (Fig. 4), due to its temporary character (lake Japșa was a shallow flooded area inside the Vărsătura Island).

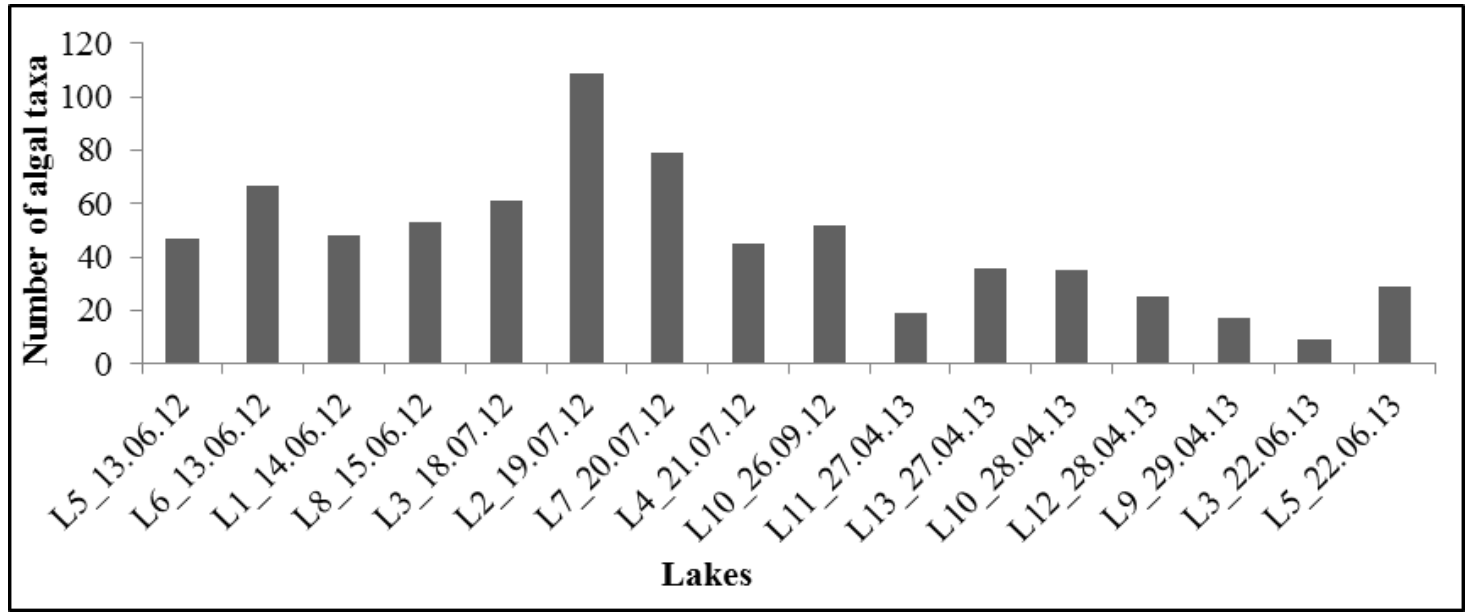

Figure 3: Number of algal taxa from the 13 lakes (16 sampling occasions) from Balta Mică a Brăilei Nature Park, arranged in chronological order (abbreviation of the sampling sites and occasions as in table 1).

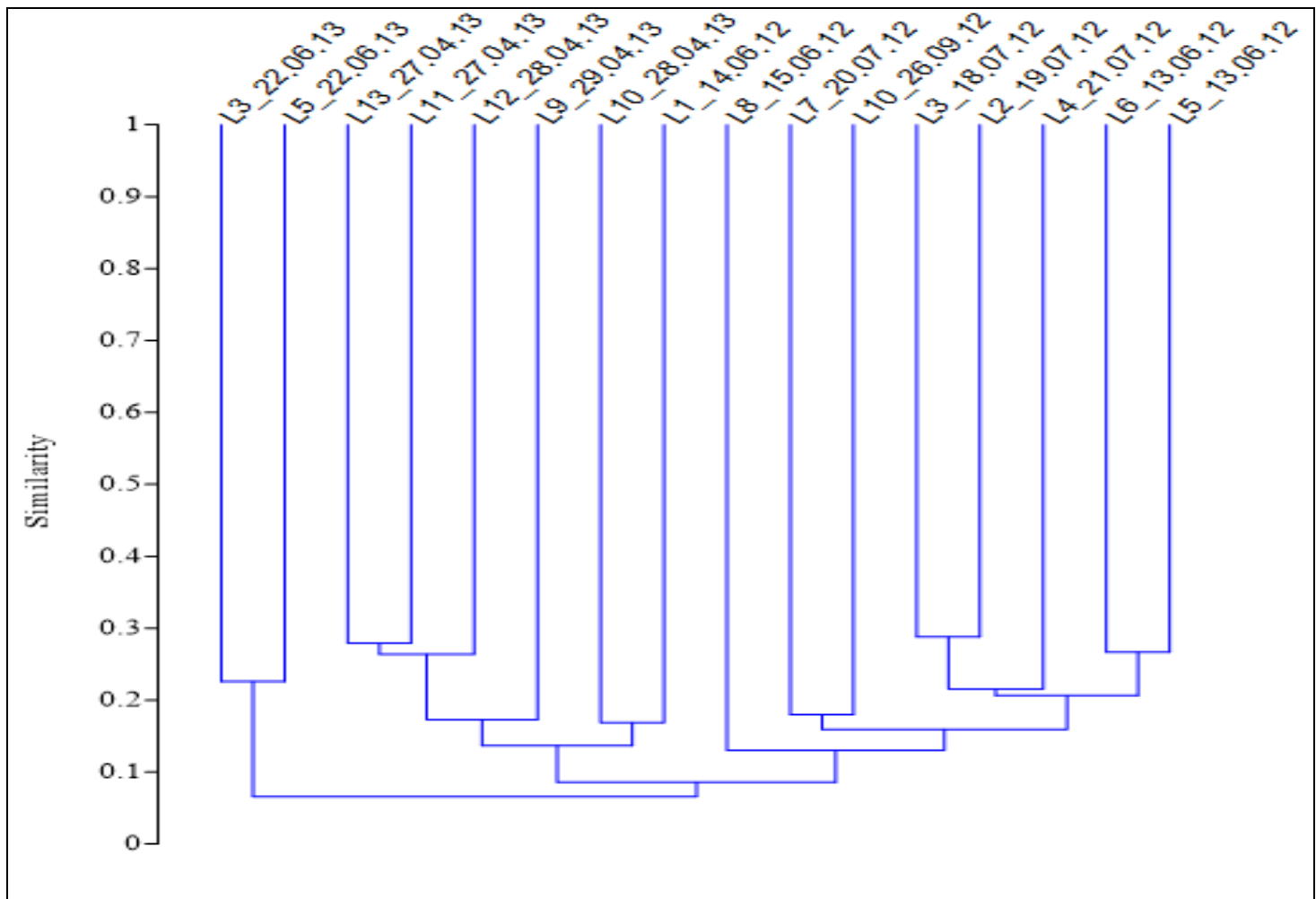

Figure 4: Jaccard similarity between the algal communities of the considered lakes from Balta Mică a Brăilei Nature Park (abbreviation of the sampling sites and occasions as in table 1). 
The distinctive separation between these clusters indicates the importance of the flood pulses, meaning that the structure of algal communities from Balta Mică a Brăilei Nature Park was highly dependent on the water-level fluctuations of the Danube, ranging from extreme low flows to maximum ones. In fact, pelagic food chains in river floodplain systems are primarily under hydrological control (Schiemer et al., 2006). Thus, in order to maintain the biodiversity of the wetland, the connectivity between the river and its floodplain lakes must be preserved, together with a variable flow regime and a sufficient spatial scale (Opperman et al., 2010).

\section{Water quality}

Water quality of the 13 sampling lakes from Balta Mică a Brăilei Nature Park area was assessed in terms of trophicity and organic pollution (saprobity), using three main indices.

Water trophicity was evaluated by the trophic index Heinonen (1980) and the compound index (Nygaard, 1949). The first one was impossible to calculate in lakes Jigara and Bordeiele (L4_21.07.12 and L10_26.09.12), because no oligotrophic species were found. The compound index was not estimated in lake Cortele (L7_20.07.12), due to the absence of species belonging to the Order Desmidiales.

In the other lakes, both indices indicated eutrophic waters in summer and autumn 2012, probably due to the nutrient concentration in the floodplain lakes, caused by the extended drought period from 2012, characterized by a lack of precipitation and high temperatures, which led to increased water evaporation (Fig. 5). On the other hand, the trophicity level dropped in 2013, probably due to changes in hydrological conditions: the high water levels from April and June 2013 washed out some of the nutrients from the lakes.

The organic pollution index showed a similar status, with strong organic pollution in 2012, due to high quantities of decomposing organic matter accumulated during summer and autumn in the water pools. In 2013 however, organic pollution was relatively low, because of the spring flush, which washed away the organic matter, facilitating its mineralization (Fig. 5).

Water bloom caused by Euglenophyta was detected in lake Sbenghiosu in July 2012. Indeed, euglenoids are known to be dominant in eutrophic lakes, where organic pollution is high (Tas and Gonulol, 2007; Bellinger and Sigee, 2010).

The lower trophic and saprobic levels shown by the lakes from Balta Mică a Brăilei Nature Park in the period of high water levels from April and June 2013 are in accordance with other findings from the middle Danube River stretch. For example, Mihaljević et al. (2010) showed that the extreme flooding of the Danube from 2006 represented a stressor that led to the transition from turbid, eutrophic-hypertrophic conditions to a clear water state in the floodplain lake Sakadaš (Kopački Rit Nature Park, Croatia).

\section{CONCLUSIONS}

A total number of 315 algal taxa were identified through sampling 13 lakes from the Balta Mică a Brăilei Nature Park in 2012 and 2013, with 11 taxa cited for the first time in Romania. The algae identified were both planktonic and benthic forms, due to the shallow depth of the sampled water pools. During high water level periods (mostly April 2013), diatom species were numerous while green algae, euglenoids and blue-greens recorded drastic decreases in species number. 
a.

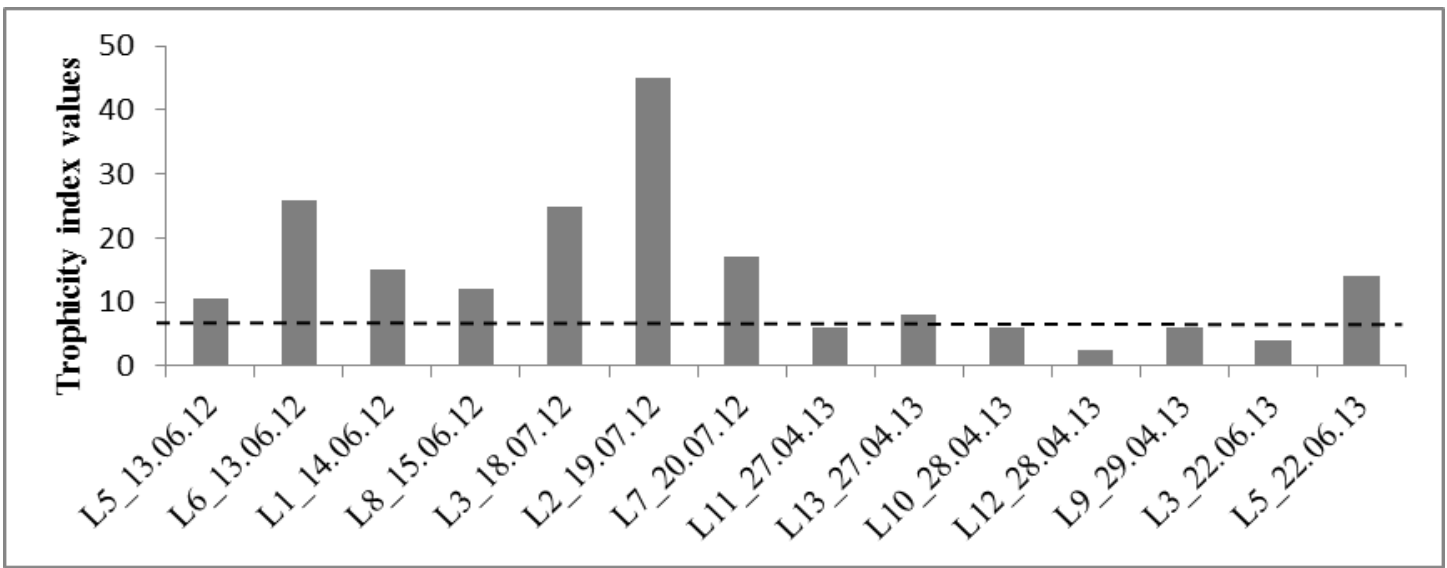

b.

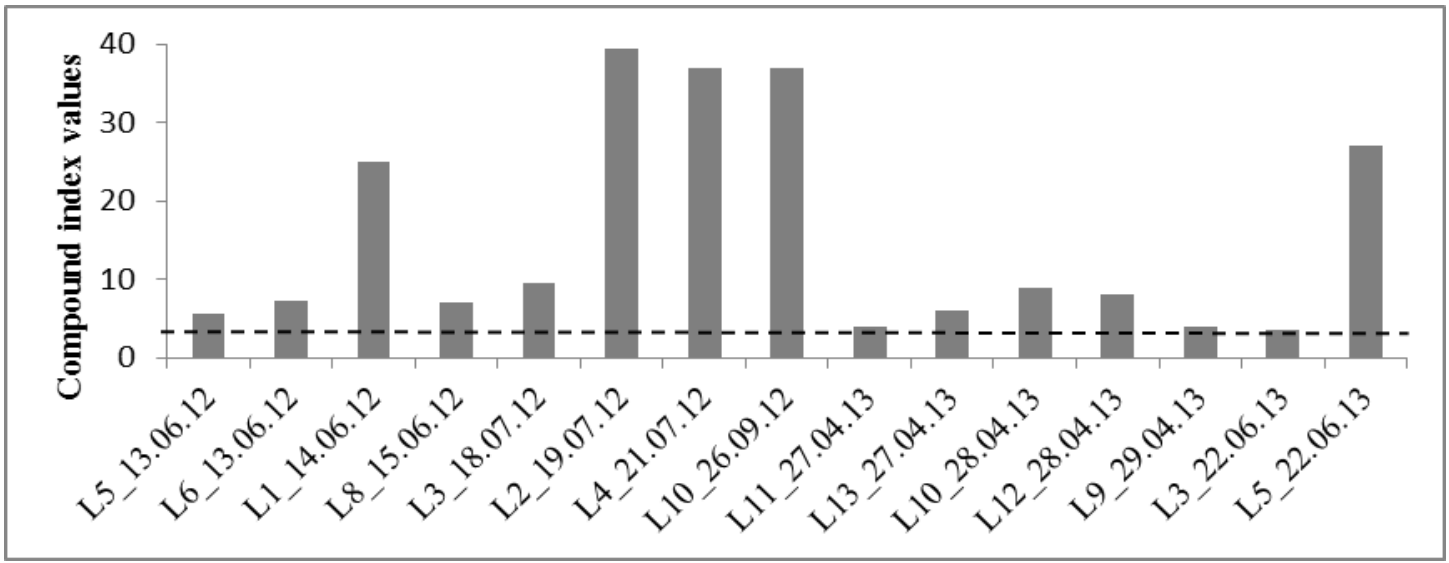

c.

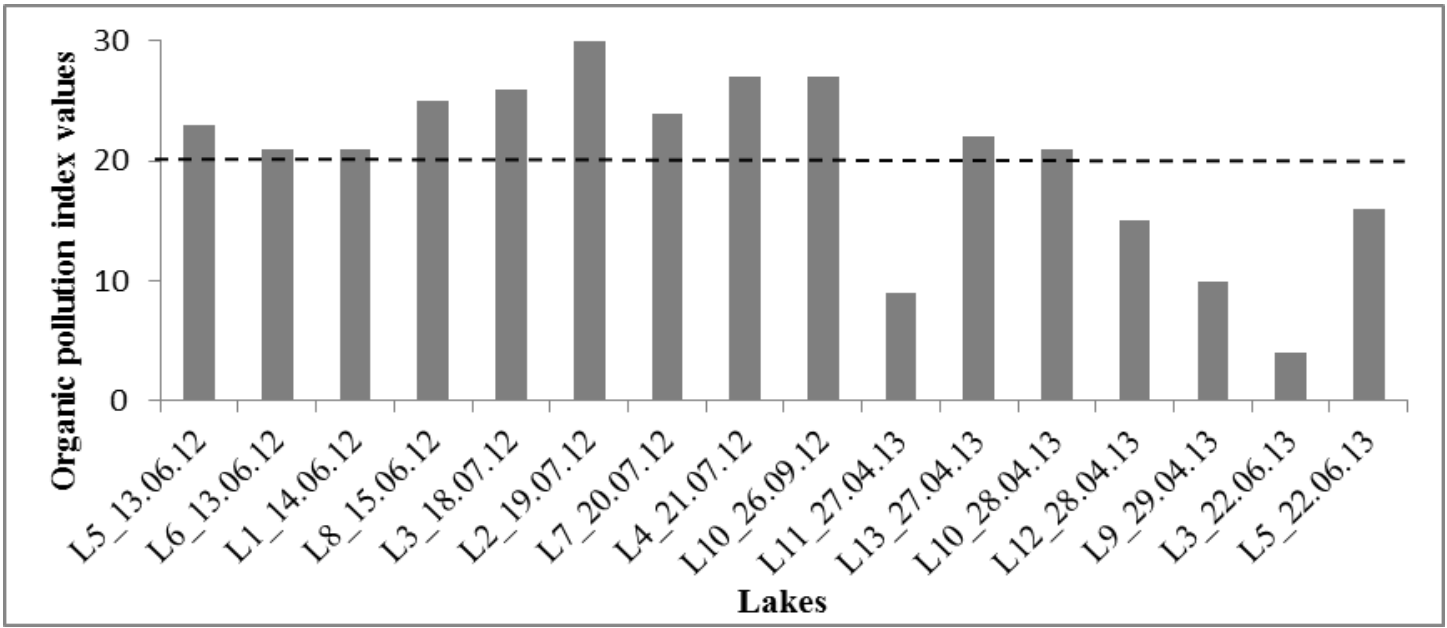

Figure 5a, b, c: Values of the trophicity and organic pollution indices (a, b, c), calculated for the sampling lakes from Balta Mică a Brăilei Nature Park, arranged in chronological order (dashed line: threshold values of the indices; abbreviation of the sampling sites and occasions as in table 1). 
The sampled lakes demonstrated great diversity in terms of microhabitats, with a corresponding diversity in algal community composition, even for lakes located quite close together.

Algal communities are dependent on the flood pulse events, and so is the trophicity and organic pollution of all the lakes from the Balta Mică a Brăilei Nature Park. The Danube brings nutrients during the spring floods; they concentrate in summer, when the lakes are isolated from the river and its arms, leading to increases in trophicity. Spring floods also wash out the decomposing organic matter accumulated in the water pools from the area, leading to accelerated mineralization and lower organic pollution. In fact, trophicity and saprobity of the sampling lakes were higher in 2012 compared to 2013, due to this flood pulse cycle.

\section{AKNOWLEDGEMENTS}

The sampling took place as part of the project "Revizuirea Ediției a II-a a Planului de Management al Parcului Natural Balta Mică a Brăilei, în contextul atribuirii statutului de SCI și SPA (Balta Mică a Brăilei Nature Park management plan: review of the second edition for the assignment of SCI and SPA status)". We recognize with gratitude the support provided to us by the administration team of Balta Mică a Brăilei Nature Park. Thanks are also given to the National Institute of Hydrology and Water Management (INHGA) and to the National Meteorological Administration, who provided the hydrologic and climatic data.

\section{REFERENCES}

1. Antonescu C. S., Popescu A., Enăceanu V. and Dumitriu M., 1952 - Rezultate preliminare asupra cercetărilor hidrobiologico-piscicole din complexul de bălți al Insulei Brăila, Comunicările Academiei, II, 9-10, 555-561. (in Romanian)

2. Bellinger E. G. and Sigee D. C., 2010 - Freshwater Algae - Identification and Use as Bioindicators, Wiley-Blackwell, Chichester, 271.

3. Brînzan T., 2013 - Catalogul habitatelor, speciilor și siturilor Natura 2000 în România, Fundația Centrul Național pentru Dezvoltare Durabilă, București, 784. (in Romanian)

4. Cărăuș I., 2012 - Algae of Romania, A distributional checklist of actual algae, Version 2.3, published in digital form, 1-809.

5. Dimitriu R. G., Pop I. C., Dudu A. C. and Melinte M. C., 2009 - Ridicări batimetrice realizate pe suprafața Parcului Natural Balta Mică a Brăilei, Volumul Sesiunii de Comunicări Științifice a Institutului Național de Geologie și Geoecologie Marină (GeoEcoMar București), 121-125. (in Romanian)

6. Ettl H. and Gärtner G., 1988 - Chlorophyta II, Tetrasporales, Chlorococcales, Gloeodendrales, in Süsswasserflora von Mitteleuropa, Ettl H., Gerloff J., Heynig H. and Mollenhauer D. (eds), 10, Gustav Fischer Verlag, Jena, 1-436.

7. Heinonen P., 1980 - Quantity and composition of phytoplankton in Finnish inland waters, Publication of the Water Research Institute, Helsinki, 37, 1-91.

8. Ionescu-Țeculescu V., 1966/1967 - Characeae din sud-vestul Dobrogei şi Balta Brăilei, Acta Botanica Horti Bucurestiensis, Bucureşti, 253-268. (in Romanian)

9. Jolliffe I. T., 2002 - Principal Component Analysis, 2nd Edit. Springer-Verlag, 1-487.

10. Komárek J. and Anagnostidis K., 2005 - Cyanoprokaryota, Oscillatoriales, in Süsswasserflora von Mitteleuropa, Büdel B., Krienitz L., Gärtner G. and Schagerl M. (eds), 19/2, Elsevier Spektrum Akademischer Verlag, 1-759. (in German)

11. Krammer K. and Lange B. H., 1986 - Bacillariophyceae, Naviculaceae, in Süsswasserflora von Mitteleuropa, Ettl H., Gerloff J., Heynig H. and Mollenhauer D. (eds), 2/1, Gustav Fischer Verlag, Jena, 1-441. (in German) 
12. Lehmann E. L., 1975 - Nonparametrics: Statistical Methods Based on Ranks, San Francisco, Holden-Day, 1-457.

13. Mihaljević M. and Stević F., 2011 - Cyanobacterial blooms in a temperate river-floodplain ecosystem: the importance of hydrological extremes, Aquatic Ecology Journal, 45, 3, 335-349.

14. Mihaljević M., Špoljarić D., Stević F., Cvijanović V. and Hackenberger K. B., 2010 - The influence of extreme floods from the river Danube in 2006 on phytoplankton communities in a floodplain lake: Shift to a clear state, Limnologica, 40, 260-268.

15. Moore P. D., 2008 - Wetlands, Revised edition, Facts On File, Inc., Infobase Publishing, 1-270.

16. Nygaard G., 1949 - Hydrobiological studies on some Danish ponds and lakes, II, The quotient hypothesis and some little known or new phytoplankton orgnisms, Det Kongelige Danske Videnskabernes Selskab, Biologiske Skrifter, 7, 1-242.

17. Opperman J. J., Luster R., McKenney B. A., Roberts M. and Meadows A. W., 2010 - Ecologically Functional Floodplains: Connectivity, Flow Regime and Scale, Journal of the American Water Resources Association, 46, 2, 211-226.

18. Palmer C. M., 1969 - A composite rating of algae tolerating organic pollution, Journal of Phycology, 5, 78-82.

19. Popovsky J. and Pfiester L. A., 1990 - Dinophyceae (Dinoflagellida), in Süsswasserflora von Mitteleuropa begründet von Pascher A., Ettl H., Gerloff J., Heynig H. and Mollenhauer D. (eds), 6, Gustav Fischer Verlag, Jena, 1-272. (in German)

20. Schiemer F., Hein T. and Peduzzi P., 2006 - Hydrological control of system characteristics of floodplain lakes, Ecohydrology and Hydrobiology, Ecohydrology for Implementation of the European Water Framework Directive, 6, 1-4, 7-18.

21. Stănescu I., Melinte M., Brustur T., Szobotka S., Cazacu C., Briceag A. and Opreanu G., 2009 Cercetări sedimentologice, geoecologice (geochimice, hidrochimice, biologice) în Parcul Natural Balta Mică a Brăilei, Volumul Sesiunii de Comunicări Științifice a Institutului Național de Geologie şi Geoecologie Marină (GeoEcoMar București), 57-68. (in Romanian)

22. Suthers I. M. and Rissik D., 2009 - The importance of plankton, in Suthers I. M. and Rissik D. (eds) Plankton: a guide to their ecology and monitoring for water quality, CSIRO Publishing, Collingwood Australia, 1-256.

23. Tas B. and Gonulol A., 2007 - An ecologic and taxonomic study on phytoplankton of a shallow lake, Turkey, Journal of Environmental Bioloy, 28, 2, 439-45.

24. Török L., 2011 - The trend of phytoplankton development in Danube Delta's lakes, Scientific Annals of the Danube Delta Institute, Tulcea, Romania, 17, 89-98.

25. Washington H. G., 1984 - Diversity, biotic and similarity indices - A review with special relevance to aquatic ecosystems, Water Research, 18, 6, 653-694.

26. Wiklund J. A., Bozinovski N., Hall R. I. and Wolfe B. B., 2010 - Epiphytic diatoms as flood indicators, Journal of Paleolimnology, 44, 1, 25-42.

27. Willén E., 2000 - Phytoplankton in water quality assessment - an indicator concept, in Hydrological and Limnological Aspects of Lake Monitoring, Heinonen P., Ziglio G. and Van der Beken A., (eds), John Wiley and Sons, 58-80.

28. Wolowski K., 2005 - Phylm Euglenophyta, in The Freshwater Algal Flora of the British Island, An identification guide for freshwater and terrestrial algae, John D. M., Whitton B. A. and Brook A. J. (eds), Cambridge University Press, 144-179.

29. *** 1971 - Convention on Wetlands of International Importance especially as Waterfowl Habitat, Ramsar (Iran), 2 February 1971, UN Treaty Series no. 14583, As amended by the Paris Protocol, 3 December 1982, and Regina Amendments, 28 May 1987.

30. *** 2000 - Directive 2000/60/EC of the European Parliament and of the Council of 23 October 2000 establishing a framework for Community action in the field of water policy, Official Journal of the European Communities, L327/72. 